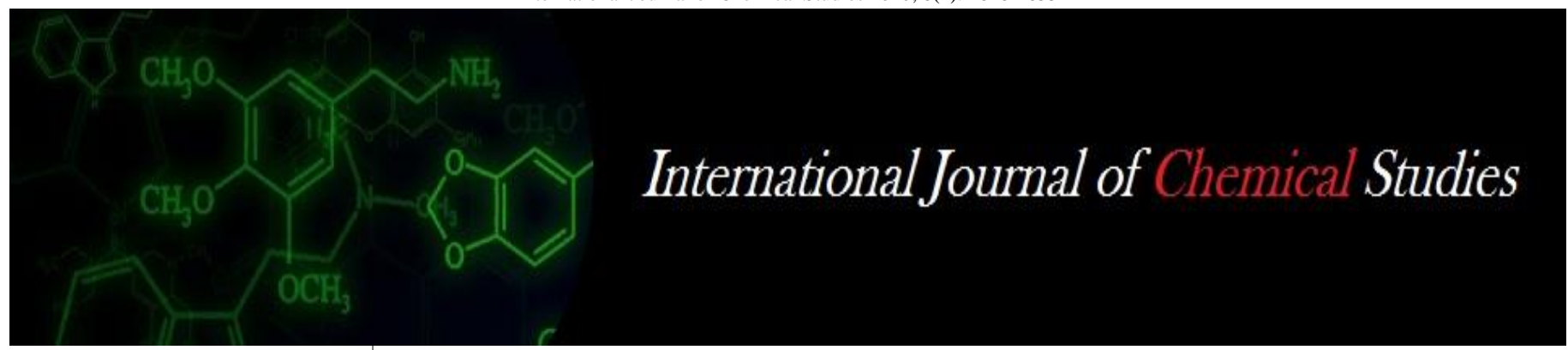

P-ISSN: 2349-8528

E-ISSN: 2321-4902

www.chemijournal.com

IJCS 2020; 8(1): 2848-2853

(C) 2020 IJCS

Received: 22-11-2019

Accepted: 24-12-2019

\section{Kumari Beauty}

Birsa Agricultural University,

Kanke, Ranchi, Jharkhand,

India

Bikash Das

ICAR Research Complex for Eastern Region, Research

Centre, Ranchi, Jharkhand,

India

\section{PR Oraon}

Birsa Agricultural University, Kanke, Ranchi, Jharkhand, India

Mahesh Kumar Dhakar ICAR Research Complex for Eastern Region, Research Centre, Ranchi, Jharkhand, India
Corresponding Author: Mahesh Kumar Dhaka ICAR Research Complex for Eastern Region, Research Centre, Ranchi, Jharkhand, India

\section{Growth performance of silvi-horti-agricultural Systems under rainfed plateau conditions of Jharkhand}

\author{
Kumari Beauty, Bikash Das, PR Oraon and Mahesh Kumar Dhakar
}

DOI: https://doi.org/10.22271/chemi.2020.v8.i1aq.8701

\begin{abstract}
The present investigation was carried out at ICAR Research Complex for Eastern Region, Research Centre, Ranchi, Jharkhand, India during 2018-2019. It was undertaken in 4-year-old, already established silvi-horticultural system. The study was laid out in split plot design. Rice and Ragi were planted in main plot whereas, subplot consisted three different silvi-horticultural systems (Mango + mahogany + aonla, Mango + mahogany + peach and Mango + mahogany + no filler). Results revealed that the growth of filler crops showed significant effect on the silvi-horti-agricultural system. The growth performance of the main crop, filler crop and inter crops varied from one system to another under silvi-horti-agricultural system. The growth parameters viz. height, girth at breast height and crown spread of forest trees were significantly higher under silvi-horti-agricutural system than sole forest plantations. Height of intercrops was significantly higher in the fallow system whereas the plant density per $\mathrm{m}^{2}$ and number of tillers per $\mathrm{m}^{2}$ after 30,60 and 90 DAS was observed significantly higher under silvi-horti-agricultural systems. Among the different silvi-horti-agricultural system, mango + mahogany + peach system performed best in terms of the growth performance of intercrops.
\end{abstract}

Keywords: Silvi-horti-agriculture system, filler crops, fallow system

\section{Introduction}

Land-use options that increase livelihood security and reduce vulnerability to climate and environmental change are necessary. The agrarian scenario of eastern plateau and hill region of India is characterized by rainfed agriculture constrained with soil acidity, high rate of soil erosion, poor water holding capacity of soil (Nath et al. 2006) ${ }^{[5]}$. The low lands and the medium uplands are used for the rainfed rice production, whereas the uplands are seldom utilized for production of agronomical crops. These uplands are either used as open pasture or for social forestry as per the conditions. Further, due to the lower productivity of rainfed crops, growing agricultural crops is unprofitable under upland conditions. Fruit tree based production system can offer suitable option for profitable utilization of the uplands. Integration of horticultural plant species provides regular income to the farmers in addition to the production from agricultural crops during the early stages of tree establishment, whereas, silvicultural species provide income in later stage sustaining the long term productivity (Kaushik and Kumar, 2003; Cooper et al., 1996) [4, 1]. A combination of Prosopis cineraria and Ziziphus mauritiana grown in agri-silvi-horticulture system had very little effect on wheat yield as an agricultural crop, thus, this system may be replicated and proposed for greater benefits in terms of fodder, fruit and food production in the arid environment (Singh et al., 2012) ${ }^{[7]}$. The agrisilvi-horticulture system proved more remunerative in arid region (Pareek, 1998) ${ }^{[6]}$, whereas, trees provide natural fertilizer to restore soil health and increase crop yield (Singh and Rathod, 2006) ${ }^{[8]}$. Improved planting stocks of silvicultural and the horticultural tree species provide multifaceted benefits and minimize the risk of total failure of system productivity as in traditional agricultural system. However, selection of a better combination of silvicultural and horticultural species seems to be more crucial to enhance the land productivity and farmers economy as compared to single species. Hence, location-specific agro-forestry system models have to be developed for increasing water use efficiency, productivity and sustainability of the system. 
Mixing of species with different growth habits, rooting patterns, and quality of leaf residues may lead to higher biomass productivity by enhancing complementary use of growth resources, reducing pest problems, and promoting greater synchrony in the release of nutrients from litter in relation to crop requirements. Conceptually to the "Central" hypothesis to justify agroforestry is that trees must utilize resources such as water and nutrients that are not utilized by crops. This means that if the existing resources are underutilized or unutilised in a crop - only system because they are inaccessible to crop roots, then spatial and/or temporal differences in rooting and root dynamics in an agroforestry system (complementarity) would be an advantage.

In these multitier systems developed at ICAR-RCER, initially light demanding intercrops are planted but later due to shading effect of perennials, either perennial were harvested before their rotation age or shade tolerant intercrops are recommended. So, it is currently unclear how to achieve optimal yields for light demanding cereals in these systems on a continuous basis. Farmers frequently grow trees interspersed with annual crops, but no scientific studies have been reported on either the optimal agronomic or horticultural practices for these conditions. The presence of trees, their structure, compositions and effect on the crop is an important area to study in this region.

This study will test the validity of the hypothesis that cerealsfruit-timber-tree based multitier cropping system can produce benefits for farmers by using resources that would not be exploited in monoculture systems and will provide an excellent case study for the potential of cereals-fruit-timbertree based systems to address the needs of resource limited farmers in marginal upland areas. Fruit and timber trees have a better chance in programs that aim for integration of perennial and annual crops to maintain ecological services and to improve overall productivity in resource limited environments. We hypothesized that integrating Mahogany and Mango as the main crop with the filler crops Aonla and Peach and annual crop Rice and Ragi, will produce relative growth advantages over the monoculture alternatives and that additional, previously underutilized light and soil water would be used by the horti-silvi alternative.

\section{Materials and Methods}

The present study was carried out on 4-year-old silvihorticultural system at ICAR Research Complex for Eastern Region, Research Centre, Ranchi, Jharkhand, India, located at $23^{\circ} 16^{\prime} 46^{\prime \prime}$ and $23^{\circ} 16^{\prime} 48^{\prime \prime} \mathrm{N}$ latitude and $85^{\circ} 24^{\prime} 48^{\prime \prime}$ and $85^{\circ}$ 24 ' 51 ' E longitude at an average elevation of $629 \mathrm{~m}(2,064 \mathrm{ft})$ above the mean sea level. The experiment was laid in split plot design. In main plot rice and ragi were taken and subplot consisted different silvi-horti-agricultural system (Mango + mahogany + aonla, Mango + mahogany + peach and Mango + mahogany + no filler). The systems consisted of 2 tree species, i.e., Mango (Mangifera indica L.) variety Amrapali and Mahogany (Swietenia mahogany) variety local and 2 horticultural species as filer crops, i.e., Peach (Prunus persica (L.) Batcsh) variety Florida Prince and Aonla (Embilica officinalis) variety NA-7 were grown. The perennial woody plants Mango and Mahogany were planted at a distance of $20 \times 20 \mathrm{~m}$ from row to row and $10 \times 10 \mathrm{~m}$ from plant to plant. Also the filler crops (Peach and Aonla) were planted at a distance of $5 \times 5 \mathrm{~m}$ from row to row and $10 \times 10 \mathrm{~m}$ from plant to plant. Rice variety Anjali and ragi variety BM 2 were sown on 20th June during 2018-19 and 12th July during 2018-19 in lines at $12 \mathrm{~cm}$ spacing respectively. Each treatment was replicated four times in the experimental plot.

The primary data of height of standing trees at ICAR-RCER, $\mathrm{RC}$, Palandu, Ranchi was recorded with the help of altimeter. The height was recorded from the base to the tip of the tree. This was calculated twice, once during sowing (initial) and other after harvesting (final). The difference in the initial and final height measurement gave the annual increment in the tree height.The primary data of girth at breast height $(\mathrm{GBH})$ of standing trees were recorded with the help of measuring tape in case of Mahogany and $5 \mathrm{~cm}$ above the ground level in case of Mango and filler crops. This was calculated twice, once during sowing (initial) and other after harvesting (final). The difference in the initial and final height measurement gave the annual increment in the tree girth.

For the value of canopy spread, the mean of spread (eastwest) and spread (north-south) was considered. This was calculated twice, once during sowing (initial) and other after harvesting (final). The difference in the initial and final height measurement gave the annual increment in the crown spread. Randomly selected plants in each plot in $1 \mathrm{~m} \times 1 \mathrm{~m}$ by using quadrate method were tagged for recording plant height at 30 , 60 and 90 DAS. The height of each plant was measured from soil surface to the base of last fully opened leaf. At harvest, the already marked plants at the time of counting of plant population; the number of tillers was recorded per meter row length.

The data were subjected to standard analysis of variance technique for split plot design. Statistical analysis was done for the individual year data for different parameters. The mean effect of treatments was compared at $\mathrm{P}<0.05$ level of significance.

\section{Results and Discussion \\ Effect of different silvi-horti-agricultural systems on growth performance of mahogany under rainfed conditions.}

The effect on growth performance of mahogany in terms of height, girth and crown spread at initial and final stage under different silvi-horti-agricultural system has been given in (Table 1). Under the main crops (rice and ragi), maximum height of mahogany tree (initial and final) was recorded in $\mathrm{A}_{1}$ (5.68 and $6.49 \mathrm{~m}$ respectively) which was significantly higher than other system $\mathrm{A}_{2}$ (5.30 and $6.31 \mathrm{~m}$ initial and final, respectively). Under the sub-plots (filler crops), the maximum height of mahogany (initial and final) was recorded in $\mathrm{B}_{2}$ (5.91 and $6.81 \mathrm{~m}$ respectively) which was significantly higher than other systems, followed by $B_{1}(5.70$ and $6.43 \mathrm{~m}$ respectively) and the lowest value was recorded in $\mathrm{B}_{3}(5.40$ and $6.20 \mathrm{~m}$ respectively). The interaction effect (A X B) were found to be non significant in influencing the height of mahogany under different silvi-horti-agricultural systems.

Similarly, under the main crops (rice and ragi), maximum girth of mahogany (initial and final) was recorded in $\mathrm{A}_{1}(5.22$ and $5.28 \mathrm{~mm}$ respectively) which was significantly higher than other system $\mathrm{A}_{2}$ (5.14 and $5.23 \mathrm{~mm}$ respectively). Under the sub-plots (filler crops), the maximum height of mahogany (initial and final) was recorded in $\mathrm{B}_{2}(5.38$ and $5.42 \mathrm{~mm}$ respectively) which was significantly higher than other systems, followed by $\mathrm{B}_{1}$ (5.15 and $5.28 \mathrm{~mm}$ respectively) and the lowest value was recorded in $\mathrm{B}_{3}(5.12$ and $5.13 \mathrm{~mm}$ respectively). The interaction effect (A X B) were found to be non significant in influencing the girth of mahogany under different silvi-horti-agricultural systems. 
Similarly, under the main crops (rice and ragi), maximum crown spread of mahogany in north-south direction (initial and final) was recorded in $\mathrm{A}_{1}$ ( 0.55 and $0.76 \mathrm{~m}$ respectively) which was significantly higher than $\mathrm{A}_{2}(0.48$ and $0.66 \mathrm{~m}$ respectively). Maximum crown spread in east west direction (initial and final) was recorded in $\mathrm{A}_{1}(0.62$ and $1.01 \mathrm{~m}$ respectively) which was significantly higher than $\mathrm{A}_{2}$ (0.59 and $0.96 \mathrm{~m}$ respectively). Under the sub-plots (filler crops), the maximum crown spread of mahogany in north-south direction (initial and final) was recorded in $\mathrm{B}_{2}(0.60$ and $0.82 \mathrm{~m}$ respectively) which was significantly higher than other systems, followed by $\mathrm{B}_{1}(0.54$ and $0.73 \mathrm{~m}$ respectively) and the lowest value was recorded in $\mathrm{B}_{3}(0.51$ and $0.70 \mathrm{~m}$ respectively). Maximum crown spread in east-west direction (initial and final) was recorded in $\mathrm{B}_{2}(0.67$ and $1.06 \mathrm{~m}$ respectively) which was significantly higher than other systems, followed by $\mathrm{B}_{1}$ ( 0.62 and $0.99 \mathrm{~m}$ respectively) and the lowest value was recorded in $\mathrm{B}_{3}(0.55$ and $0.98 \mathrm{~m}$ respectively). The interaction effect (A X B) were found to be non significant in influencing the crown spread of mahogany under different silvi-horti-agricultural systems.

Table 1: Effect of different silvi-horti-agricultural systems on growth performance of mahogany under rainfed conditions

\begin{tabular}{|c|c|c|c|c|c|c|c|c|}
\hline \multirow{3}{*}{ Treatments } & \multirow{2}{*}{\multicolumn{2}{|c|}{ Height (m) }} & \multirow{2}{*}{\multicolumn{2}{|c|}{ Girth (mm) }} & \multicolumn{4}{|c|}{ Crown spread (m) } \\
\hline & & & & & \multicolumn{2}{|c|}{ N-S } & \multicolumn{2}{|c|}{ E-W } \\
\hline & Initial & Final & Initial & Final & Initial & Final & Initial & Final \\
\hline $\mathrm{A}_{1}$ & 5.68 & 6.49 & 5.22 & 5.28 & 0.55 & 0.76 & 0.62 & 1.01 \\
\hline $\mathrm{A}_{2}$ & 5.30 & 6.31 & 5.14 & 5.23 & 0.48 & 0.66 & 0.59 & 0.96 \\
\hline C.D. at $5 \%$ & 0.33 & 0.15 & 0.06 & 0.03 & 0.06 & 0.09 & 0.012 & 0.03 \\
\hline $\mathrm{SE}(\mathrm{m}) \pm$ & 0.11 & 0.05 & 0.02 & 0.01 & 0.02 & 0.03 & 0.004 & 0.01 \\
\hline & & & & & & & & \\
\hline $\mathrm{B}_{1}$ & 5.70 & 6.43 & 5.15 & 5.28 & 0.54 & 0.73 & 0.62 & 0.99 \\
\hline $\mathrm{B}_{2}$ & 5.91 & 6.81 & 5.38 & 5.42 & 0.60 & 0.82 & 0.67 & 1.06 \\
\hline $\mathrm{B}_{3}$ & 5.40 & 6.20 & 5.12 & 5.13 & 0.51 & 0.70 & 0.55 & 0.98 \\
\hline C.D. at $5 \%$ & 0.18 & 0.11 & 0.05 & 0.06 & 0.04 & 0.03 & 0.03 & 0.02 \\
\hline $\mathrm{SE}(\mathrm{m}) \pm$ & 0.06 & 0.04 & 0.02 & 0.02 & 0.01 & 0.01 & 0.01 & 0.006 \\
\hline & & & & & & & & \\
\hline $\mathrm{A}_{1} \mathrm{XB}_{1}$ & 5.71 & 6.43 & 5.16 & 5.28 & 0.54 & 0.74 & 0.62 & 0.99 \\
\hline $\mathrm{A}_{1} \mathrm{XB}_{2}$ & 5.90 & 6.82 & 5.38 & 5.45 & 0.61 & 0.82 & 0.68 & 1.06 \\
\hline $\mathrm{A}_{1} \mathrm{XB}_{3}$ & 5.40 & 6.21 & 5.13 & 5.15 & 0.51 & 0.73 & 0.55 & 0.98 \\
\hline $\mathrm{A}_{2} \mathrm{XB}_{1}$ & 5.70 & 6.42 & 5.15 & 5.28 & 0.53 & 0.73 & 0.61 & 0.99 \\
\hline $\mathrm{A}_{2} \mathrm{XB}_{2}$ & 5.91 & 6.80 & 5.38 & 5.41 & 0.60 & 0.82 & 0.67 & 1.06 \\
\hline $\mathrm{A}_{2} \mathrm{XB}_{3}$ & 5.39 & 6.19 & 5.11 & 5.11 & 0.50 & 0.70 & 0.54 & 0.97 \\
\hline C.D. at $5 \%(\mathrm{~B}-\mathrm{A})$ & $\mathrm{NS}$ & $\mathrm{NS}$ & $\mathrm{NS}$ & $\mathrm{NS}$ & $\mathrm{NS}$ & $\mathrm{NS}$ & $\mathrm{NS}$ & $\mathrm{NS}$ \\
\hline $\mathrm{SE}(\mathrm{m}) \pm$ & 0.12 & 0.07 & 0.03 & 0.04 & 0.03 & 0.03 & 0.02 & 0.02 \\
\hline C.D. at $5 \%(\mathrm{~A}-\mathrm{B})$ & $\mathrm{NS}$ & $\mathrm{NS}$ & NS & NS & NS & NS & NS & NS \\
\hline $\mathrm{SE}(\mathrm{m}) \pm$ & 0.15 & 0.08 & 0.03 & 0.03 & 0.03 & 0.04 & 0.02 & 0.02 \\
\hline $\mathrm{CV} \%$ & 7.56 & 8.25 & 7.56 & 7.42 & 7.33 & 7.65 & 8.02 & 7.74 \\
\hline
\end{tabular}

$\mathrm{A}_{1}=$ Rice, $\mathrm{A}_{2}=$ Ragi, $\mathrm{B}_{1}=$ Mango + mahogany + aonla, $\mathrm{B}_{2}=$ Mango + mahogany + peach, $\mathrm{B}_{3}=$ Mango + mahogany + no filler, NS=non significant.

\section{Effect of different silvi-horti-agricultural systems on growth performance of mango under rainfed conditions.}

The effect on growth performance of mango in terms of height, girth and crown spread at initial and final stage under different silvi-horti-agricultural system has been given in table 2. Under the main crops (rice and ragi), maximum height of mango (initial and final) was recorded in $\mathrm{A}_{1}(1.37$ and $1.40 \mathrm{~m}$ respectively) which was significantly higher than other system $\mathrm{A}_{2}$ (1.30 and $1.34 \mathrm{~m}$ respectively). Under the sub-plots (filler crops), the maximum height of mango (initial and final) was recorded in $\mathrm{B}_{2}$ (1.47 and $1.49 \mathrm{~m}$ respectively) which was significantly higher than other systems, followed by $\mathrm{B}_{1}$ (1.37 and $6.43 \mathrm{~m}$ respectively) and the lowest value was recorded in $B_{3}$ (1.34 and $1.37 \mathrm{~m}$ respectively). The interaction effect (A X B) were found to be non significant in influencing the height of mango under different silvi-horti-agricultural systems.

Similarly, under the main crops (rice and ragi), maximum girth of mango (initial and final) was recorded in $A_{1}$ (4.35 and $4.36 \mathrm{~mm}$ respectively) which was significantly higher than other system $\mathrm{A}_{2}$ (4.29 and $4.31 \mathrm{~mm}$ respectively). Under the sub-plots (filler crops), the maximum height of mango (initial and final) was recorded in $\mathrm{B}_{2}$ (4.38 and $4.39 \mathrm{~mm}$ respectively) which was significantly higher than other systems, followed by $\mathrm{B}_{1}(4.35$ and $4.37 \mathrm{~mm}$ respectively) and the lowest value was recorded in $\mathrm{B}_{3}$ (4.32 and $4.33 \mathrm{~mm}$ respectively). The interaction effect (A X B) were found to be non significant in influencing the girth of mango under different silvi-hortiagricultural systems.

Similarly, under the main crops (rice and ragi), maximum crown spread of mango in north-south direction (initial and final) was recorded in $A_{1}$ ( 0.35 and $0.38 \mathrm{~m}$ respectively) which was significantly higher than $\mathrm{A}_{2}(0.32$ and $0.35 \mathrm{~m}$ respectively). Maximum crown spread in east-west direction (initial and final) was recorded in $A_{1}(0.39$ and $0.41 \mathrm{~m}$ respectively) which was significantly higher than $\mathrm{A}_{2}$ ( 0.36 and $0.38 \mathrm{~m}$ respectively).Under the sub-plots (filler crops), the maximum crown spread of mango in north-south direction (initial and final) was recorded in $\mathrm{B}_{2}(0.38$ and $0.41 \mathrm{~m}$ respectively) which was significantly higher than other systems, followed by $\mathrm{B}_{1}(0.35$ and $0.38 \mathrm{~m}$ respectively) and the lowest value was recorded in $\mathrm{B}_{3}(0.31$ and $0.35 \mathrm{~m}$ respectively). Maximum crown spread in east-west direction (initial and final) was recorded in $\mathrm{B}_{2}(0.42$ and $0.45 \mathrm{~m}$ respectively) which was significantly higher than other systems, followed by $\mathrm{B}_{1}$ ( 0.38 and $0.41 \mathrm{~m}$ respectively) and the lowest value was recorded in $\mathrm{B}_{3}(0.36$ and $0.39 \mathrm{~m}$ respectively). The interaction effect (A X B) were found to be non significant in influencing the crown spread of mango under different silvi-horti-agricultural systems. 
Table 2: Effect of different silvi-horti-agricultural systems on growth performance of mango under rainfed conditions

\begin{tabular}{|c|c|c|c|c|c|c|c|c|}
\hline \multirow{3}{*}{ Treatments } & \multirow{2}{*}{\multicolumn{2}{|c|}{ Height (m) }} & \multirow{2}{*}{\multicolumn{2}{|c|}{ Girth (mm) }} & \multicolumn{4}{|c|}{ Crown spread (m) } \\
\hline & & & & & \multicolumn{2}{|c|}{ N-S } & \multicolumn{2}{|c|}{ E-W } \\
\hline & Initial & Final & Initial & Final & Initial & Final & Initial & Final \\
\hline $\mathrm{A}_{1}$ & 1.37 & 1.40 & 4.35 & 4.36 & 0.35 & 0.38 & 0.39 & 0.41 \\
\hline $\mathrm{A}_{2}$ & 1.30 & 1.34 & 4.29 & 4.31 & 0.32 & 0.35 & 0.36 & 0.38 \\
\hline C.D. at 5\% & 0.06 & 0.06 & 0.03 & 0.027 & 0.012 & 0.009 & 0.006 & 0.015 \\
\hline $\mathrm{SE}(\mathrm{m}) \pm$ & 0.02 & 0.02 & 0.01 & 0.009 & 0.004 & 0.003 & 0.002 & 0.005 \\
\hline & & & & & & & & \\
\hline $\mathrm{B}_{1}$ & 1.37 & 1.39 & 4.35 & 4.37 & 0.35 & 0.38 & 0.38 & 0.41 \\
\hline $\mathrm{B}_{2}$ & 1.47 & 1.49 & 4.38 & 4.39 & 0.38 & 0.41 & 0.42 & 0.45 \\
\hline $\mathrm{B}_{3}$ & 1.34 & 1.37 & 4.32 & 4.33 & 0.31 & 0.35 & 0.36 & 0.39 \\
\hline C.D. at 5\% & 0.03 & 0.04 & 0.03 & 0.03 & 0.01 & 0.01 & 0.01 & 0.01 \\
\hline $\mathrm{SE}(\mathrm{m}) \pm$ & 0.01 & 0.01 & 0.01 & 0.01 & 0.003 & 0.003 & 0.003 & 0.003 \\
\hline $\mathrm{A}_{\mathrm{X}} \mathrm{B}_{1}$ & 137 & 139 & 436 & 437 & 0353 & 038 & 038 & 044 \\
\hline$\frac{\mathrm{A}_{1} \mathrm{X} \mathrm{B}_{1}}{\mathrm{~A}_{1} \mathrm{XB}_{2}}$ & $\frac{1.37}{1.44}$ & $\begin{array}{l}1.39 \\
1.45\end{array}$ & $\begin{array}{l}4.36 \\
4.38\end{array}$ & $\frac{4.31}{4.39}$ & 0.38 & 0.41 & $\begin{array}{l}0.50 \\
0.42\end{array}$ & $\begin{array}{l}0.41 \\
0.45\end{array}$ \\
\hline $\mathrm{A}_{1} \mathrm{XB}_{3}$ & 1.32 & 1.35 & 4.31 & 4.32 & 0.31 & 0.34 & 0.37 & 0.39 \\
\hline $\mathrm{A}_{2} \mathrm{XB}_{1}$ & 1.37 & 1.39 & 4.35 & 4.36 & 0.35 & 0.38 & 0.38 & 0.41 \\
\hline $\mathrm{A}_{2} \mathrm{XB}_{2}$ & 1.44 & 1.48 & 4.38 & 4.39 & 0.37 & 0.41 & 0.42 & 0.45 \\
\hline $\mathrm{A}_{2} \mathrm{XB}_{3}$ & 1.34 & 1.38 & 4.33 & 4.34 & 0.31 & 0.35 & 0.37 & 0.39 \\
\hline C.D. at $5 \%(B-A)$ & NS & NS & NS & NS & NS & NS & NS & NS \\
\hline $\mathrm{SE}(\mathrm{m}) \pm$ & 0.02 & 0.03 & 0.02 & 0.02 & 0.008 & 0.008 & 0.008 & 0.007 \\
\hline C.D. at $5 \%$ (A-B) & NS & NS & NS & NS & NS & NS & NS & NS \\
\hline $\mathrm{SE}(\mathrm{m}) \pm$ & 0.02 & 0.03 & 0.02 & 0.02 & 0.007 & 0.007 & 0.007 & 0.005 \\
\hline $\mathrm{CV} \%$ & 7.40 & 7.21 & 7.51 & 7.35 & 7.28 & 7.35 & 7.45 & 7.26 \\
\hline
\end{tabular}

A1=Rice, A2=Ragi, B1=Mango + mahogany + aonla, B2= Mango + mahogany + peach, B3=Mango + mahogany + no filler, NS=non significant.

\section{Effect of different silvi-horti-agricultural systems on growth performance of aonla and peach under rainfed conditions}

Analysis of data is presented in the table 3 which reveals the effect on growth performance of aonla and peach in terms of height, girth and crown spread at initial and final stage under different silvi-horti-agricultural system and it can be inferred from the table that under the main crops (rice and ragi), maximum mean height of filler crops (initial and final) was recorded in $\mathrm{A}_{1}$ (2.65 and $3.20 \mathrm{~m}$ respectively) which was significantly higher than other system $\mathrm{A}_{2}$ (2.55 and $3.12 \mathrm{~m}$ respectively). Among the sub-plots (filler crops), the maximum height was recorded in peach $(2.83$ and $3.31 \mathrm{~m}$ initial and final, respectively) which was significantly higher than other system aonla (2.45 and $3.10 \mathrm{~m}$ respectively). The interaction effect (A X B) were found to be non significant in influencing the height of aonla and peach under different silvi-horti-agricultural systems.

Similarly, under the main crops (rice and ragi), maximum girth of filler crops (initial and final) was recorded in $\mathrm{A}_{1}$ (7.74 and $8.28 \mathrm{~mm}$ respectively) which was significantly higher than $\mathrm{A}_{2}$ (7.61 and $8.00 \mathrm{~mm}$ respectively). Among the subplots (filler crops), the maximum girth was recorded in peach
(9.01 and $9.41 \mathrm{~mm}$ respectively) which was significantly higher than aonla (6.45 and $7.15 \mathrm{~mm}$ respectively).The interaction effect (A X B) were found to be non significant in influencing the girth of aonla and peach under different Silvihorti-agricultural systems.

Similarly, under the main crops (rice and ragi), mean maximum crown spread of filler crops in north-south direction (initial and final) was recorded in $\mathrm{A}_{1}$ (2.16 and 2.43 $m$ respectively) which was significantly higher than $A_{2}(2.12$ and $2.29 \mathrm{~m}$ respectively). Maximum crown spread in east-west direction (initial and final) was recorded in $\mathrm{A}_{1}$ (2.23 and 2.56 $m$ respectively) which was significantly higher than $A_{2}(2.26$ and $2.51 \mathrm{~m}$ respectively).Under the sub-plots (filler crops), the maximum crown spread was recorded in peach (2.41 and 2.74 $\mathrm{m}$ respectively) which was significantly higher than aonla (1.89 and $2.12 \mathrm{~m}$ respectively). Maximum crown spread in east-west direction (initial and final) was recorded in peach ( 2.55 and $2.85 \mathrm{~m}$ respectively) which was significantly higher than aonla (1.92 and $2.54 \mathrm{~m}$ respectively). The interaction effect (A X B) were found to be non significant in influencing the crown spread of aonla and peach under different silvihorti-agricultural systems.

Table 3: Effect of different silvi-horti-agricultural systems on growth performance of aonla and peach under rainfed conditions

\begin{tabular}{|c|c|c|c|c|c|c|c|c|}
\hline \multirow{3}{*}{ Treatments } & \multirow{2}{*}{\multicolumn{2}{|c|}{ Height (m) }} & \multirow{2}{*}{\multicolumn{2}{|c|}{ Girth (mm) }} & \multicolumn{4}{|c|}{ Crown spread (m) } \\
\hline & & & & & \multicolumn{2}{|c|}{ NS } & \multicolumn{2}{|c|}{ EW } \\
\hline & Initial & Final & Initial & Final & Initial & Final & Initial & Final \\
\hline $\mathrm{A}_{1}$ & 2.65 & 3.20 & 7.74 & 8.28 & 2.16 & 2.43 & 2.26 & 2.56 \\
\hline $\mathrm{A}_{2}$ & 2.55 & 3.12 & 7.61 & 8.00 & 2.12 & 2.29 & 2.23 & 2.51 \\
\hline C.D. at $5 \%$ & 0.09 & 0.06 & 0.12 & 0.27 & 0.03 & 0.12 & 0.018 & 0.018 \\
\hline $\mathrm{SE}(\mathrm{m}) \pm$ & 0.03 & 0.02 & 0.04 & 0.09 & 0.01 & 0.04 & 0.006 & 0.006 \\
\hline & & & & & & & & \\
\hline $\mathrm{B}_{1}$ & 2.45 & 3.10 & 6.45 & 7.15 & 1.89 & 2.12 & 1.92 & 2.54 \\
\hline $\mathrm{B}_{2}$ & 2.83 & 3.31 & 9.01 & 9.41 & 2.41 & 2.74 & 2.55 & 2.85 \\
\hline C.D. at $5 \%$ & 0.08 & 0.06 & 0.09 & 0.13 & 0.06 & 0.09 & 0.02 & 0.03 \\
\hline $\mathrm{SE}(\mathrm{m}) \pm$ & 0.03 & 0.02 & 0.03 & 0.04 & 0.02 & 0.03 & 0.006 & 0.01 \\
\hline
\end{tabular}




\begin{tabular}{|c|c|c|c|c|c|c|c|c|}
\hline $\mathrm{A}_{1} \mathrm{XB}_{1}$ & 2.45 & 3.10 & 6.46 & 7.14 & 1.90 & 2.15 & 1.92 & 2.26 \\
\hline $\mathrm{A}_{1} \mathrm{XB}_{2}$ & 2.84 & 3.30 & 9.02 & 9.41 & 2.42 & 2.74 & 2.55 & 2.86 \\
\hline $\mathrm{A}_{2} \mathrm{XB}_{1}$ & 2.45 & 3.09 & 6.44 & 7.16 & 1.89 & 2.12 & 1.92 & 2.24 \\
\hline $\mathrm{A}_{2} \mathrm{XB} 2$ & 2.82 & 3.32 & 9.01 & 9.40 & 2.41 & 2.74 & 2.54 & 2.85 \\
\hline C.D. at 5\% (B-A) & $\mathrm{NS}$ & $\mathrm{NS}$ & $\mathrm{NS}$ & $\mathrm{NS}$ & $\mathrm{NS}$ & $\mathrm{NS}$ & $\mathrm{NS}$ & $\mathrm{NS}$ \\
\hline $\mathrm{SE}(\mathrm{m}) \pm$ & 0.05 & 0.04 & 0.05 & 0.13 & 0.01 & 0.06 & 0.008 & 0.009 \\
\hline C.D. at 5\% (A-B) & $\mathrm{NS}$ & $\mathrm{NS}$ & $\mathrm{NS}$ & $\mathrm{NS}$ & $\mathrm{NS}$ & $\mathrm{NA}$ & $\mathrm{NS}$ & NS \\
\hline $\mathrm{SE}(\mathrm{m}) \pm$ & 0.05 & 0.04 & 0.06 & 0.10 & 0.01 & 0.05 & 0.008 & 0.02 \\
\hline $\mathrm{CV} \%$ & 5.61 & 5.64 & 6.23 & 6.83 & 7.42 & 7.56 & 6.59 & 6.86 \\
\hline
\end{tabular}

$\mathrm{A}_{1}=$ Rice, $\mathrm{A}_{2}=$ Ragi, $\mathrm{B}_{1}=$ Mango + mahogany + aonla, $\mathrm{B}_{2}=$ Mango + mahogany + peach, NS=non significant.

The growth parameters viz. height, diameter at breast height and crown spread of trees were significantly higher under silvi-horti-agricultural system. This may be because of the soil nutrient enrichment by the filler crops. Among the different systems it was comparatively higher in mango + mahogany + peach + rice system. This may be due to higher moisture content and soil enrichment due to litter fall under the peach system.

The observations are in line with Swain (2014) ${ }^{[9]}$ that the Mango + Guava + Cowpea intercropping system exhibited better performance which has been reflected in the form of plant height, girth, canopy area, fruit weight and fruit yield of mango closely followed by Mango + Guava + French bean system. Also Das et al. (2017) ${ }^{[2]}$ also observed the enhanced growth of mango and filler plants with paddy as intercrop. Incorporation of trees improved the soil organic matter status compared to sole coconut plots. Singh et al. (2012) ${ }^{[7]}$ studied the effect of tree species on improvement of soil fertility status. Their studies revealed that the concentration and accumulation of nutrients were higher under trees than control.

\section{Effect of different silvi-horti-agricultural systems on growth performance of intercrops under rainfed conditions}

Analysis of the data presented in the table 4 shows the growth performance of intercrops under different silvi-hortiagricultural systems and it is evident from the table 4 that under the main crops (rice and ragi), maximum value of plant density per $\mathrm{m}^{2}$ after 30,60 and 90 days of sowing was observed in $\mathrm{A}_{1}\left(94.68,104.56\right.$ and 104.56 per $\mathrm{m}^{2}$ respectively) which is significantly higher than $A_{2}$ (19.50, 21.31 and 21.31 per $\mathrm{m}^{2}$ respectively). Under the sub-plots (filler crops), maximum value of plant density per $\mathrm{m}^{2}$ after 30,60 and 90 days of sowing was observed in $\mathrm{B}_{1}(62.75,71.62$ and 71.62 per $\mathrm{m}^{2}$ respectively) which was at par with $\mathrm{B}_{2}(61.75,71.37$ and 71.37 per $\mathrm{m}^{2}$ respectively), followed by $\mathrm{B}_{3}(52.37,55.25$ and 55.25 per $\mathrm{m}^{2}$ respectively) and the minimum value was recorded in $\mathrm{B}_{4}\left(51.50,53.50\right.$ and 53.50 per $\mathrm{m}^{2}$ respectively). The interaction effect (A $\mathrm{X}$ B) were found to be non significant in influencing the density of intercrops under different silvi-horti-agricultural systems.

The maximum value of plant height under the main crops (rice and ragi), after 30, 60 and 90 days of sowing were observed in $A_{1}$ (24.18, 70.43 and $119.68 \mathrm{~m}$ respectively) which is significantly higher than $\mathrm{A}_{2}(13.37,54.93$ and 110.25 $\mathrm{m}$ respectively). Under the sub-plots (filler crops), the maximum value of plant height after 30, 60 and 90 days of sowing was observed in $\mathrm{B}_{4}(20.25,64.00$ and $118.87 \mathrm{~cm}$ respectively) which was at par with $\mathrm{B}_{3}(20.31,63.50$ and $117.87 \mathrm{~cm}$ respectively), followed by $\mathrm{B}_{1}(17.25,61.50$ and $112.62 \mathrm{~cm}$ respectively) and the minimum value was observed in $\mathrm{B}_{2}(16.31,59.75$ and $110.50 \mathrm{~cm}$ respectively). The interaction effect (A $\mathrm{X} B$ ) were found to be non significant in influencing the height of intercrops under different silvi-horti-agricultural systems.

The maximum number of tillers per $\mathrm{m}^{2}$ under the main crops (rice and ragi), after 30, 60 and 90 days of sowing were observed in $A_{1}\left(145.37,154.00\right.$ and 154.00 per $\mathrm{m}^{2}$ respectively) which is significantly higher than $A_{2}$ (85.37 and 91.31 per $\mathrm{m}^{2}$ respectively). Under the sub-plots (filler crops), the maximum number of tillers per $\mathrm{m}^{2}$ after 30,60 and 90 days of sowing was observed in $\mathrm{B}_{1}(130.00,142.50$ and 142.50 per $\mathrm{m}^{2}$ respectively) which was at par with $\mathrm{B}_{2}(129.25$, 136.87 and 136.87 per $\mathrm{m}^{2}$ respectively), followed by $B_{3}$ (102.00, 107.62 and 107.62 per $\mathrm{m}^{2}$ respectively) and the minimum number was observed in $\mathrm{B}_{4}(100.00,106.62$ and 106.62 per $\mathrm{m}^{2}$ respectively). The data also reveals that there was no change in the number of plant density and tillers per $\mathrm{m}^{2}$ after 60 days of sowing. The interaction effect (A X B) were found to be non significant in influencing the number of tillers of intercrops under different silvi-horti-agricultural systems.

The plant density and the number of tillers per $\mathrm{m}^{2}$ were higher in silvi-horti-agricultural system. It might be due to moisture availability in agri-silvi-horticultural system, which is an important factor for the germination of seeds. The reason of moisture availability in agri-silvi-horticultural system was tree canopy, which reduced evaporation loss of soil surface.The plant density and number of tillers was higher under mango + Mahogany + Aonla + Rice system as the small leaves of aonla leads to greater penetration of light for the inter crops in comparison to peach tree. The maximum height was recorded under sole crop system then under agri-silvi-horticultural system, which is in line with the observations of Tripathi et al. (2006) ${ }^{[10]}$. This might be attributed to reduced light intensity under silvi-horti-agricultural system. Therefore, reduced light intensity in silvi-horti-agricultural system decreased the photosynthetic efficiency of crops resulting in poor growth performance. The present findings are in line with the result of Dhillon et al. (2012) ${ }^{[3]}$. 
Table 4: Effect of different silvi-horti-agricultural systems on growth performance of intercrops under rainfed conditions.

\begin{tabular}{|c|c|c|c|c|c|c|c|c|c|}
\hline \multirow[b]{2}{*}{ Parameters } & \multicolumn{3}{|c|}{30 DAS } & \multicolumn{3}{|c|}{60 DAS } & \multicolumn{3}{|c|}{90 DAS } \\
\hline & $\begin{array}{c}\text { Plant } \\
\text { density } / \mathrm{m}^{2}\end{array}$ & $\begin{array}{l}\text { Plant height } \\
\text { (cm) }\end{array}$ & $\begin{array}{l}\text { Tillers } \\
\text { No. } / \mathrm{m}^{2}\end{array}$ & $\begin{array}{c}\text { Plant } \\
\text { density/m² }\end{array}$ & $\begin{array}{c}\text { Plant } \\
\text { height }(\mathrm{cm})\end{array}$ & $\begin{array}{c}\text { Tillers } \\
\text { No./m² }\end{array}$ & $\begin{array}{c}\text { Plant } \\
\text { density/m² }\end{array}$ & $\begin{array}{c}\text { Plant } \\
\text { height }(\mathrm{cm})\end{array}$ & $\begin{array}{l}\text { Tillers } \\
\text { No./m² }\end{array}$ \\
\hline $\mathrm{A}_{1}$ & 94.68 & 24.18 & 145.37 & 104.56 & 70.43 & 154.00 & 104.56 & 119.68 & 154.00 \\
\hline $\mathrm{A}_{2}$ & 19.50 & 13.37 & 85.37 & 21.31 & 54.93 & 91.31 & 21.31 & 110.25 & 91.31 \\
\hline C.D. at $5 \%$ & 3.05 & 1.37 & 4.05 & 3.86 & 6.21 & 4.98 & 3.86 & 1.18 & 4.98 \\
\hline $\mathrm{SE}(\mathrm{d}) \pm$ & 0.92 & 0.41 & 1.22 & 1.17 & 1.88 & 1.51 & 1.17 & 0.35 & 1.51 \\
\hline & & & & & & & & & \\
\hline $\mathrm{B}_{1}$ & 62.75 & 17.25 & 130.00 & 71.62 & 61.50 & 142.50 & 71.62 & 112.62 & 142.50 \\
\hline $\mathrm{B}_{2}$ & 61.75 & 16.31 & 129.25 & 71.37 & 59.75 & 136.87 & 71.37 & 110.50 & 136.87 \\
\hline $\mathrm{B}_{3}$ & 52.37 & 20.31 & 102.00 & 55.25 & 63.50 & 107.62 & 55.25 & 117.87 & 107.62 \\
\hline $\mathrm{B}_{4}$ & 51.50 & 20.25 & 100.00 & 53.50 & 64.00 & 106.62 & 53.50 & 118.87 & 106.62 \\
\hline C.D. at 5\% & 3.41 & 1.11 & 5.88 & 2.73 & 2.80 & 6.55 & 2.73 & 3.01 & 6.55 \\
\hline $\mathrm{SE}(\mathrm{d}) \pm$ & 1.14 & 0.37 & 1.96 & 0.91 & 0.93 & 2.18 & 0.91 & 1.00 & 2.18 \\
\hline & & & & & & & & & \\
\hline $\mathrm{A}_{1} \mathrm{XB}_{1}$ & 103.50 & 13.00 & 163.25 & 119.50 & 53.50 & 183.50 & 119.50 & 105.75 & 183.50 \\
\hline $\mathrm{A}_{1} \mathrm{XB}_{2}$ & 101.25 & 12.62 & 163.75 & 119.75 & 52.25 & 168.00 & 119.75 & 106.00 & 168.00 \\
\hline $\mathrm{A}_{1} \mathrm{XB}_{3}$ & 88.75 & 13.87 & 126.25 & 91.50 & 58.50 & 131.00 & 91.50 & 114.50 & 131.00 \\
\hline $\mathrm{A}_{1} \mathrm{XB}_{4}$ & 85.25 & 14.00 & 128.25 & 87.50 & 55.50 & 133.50 & 87.50 & 114.75 & 133.50 \\
\hline $\mathrm{A}_{2} \mathrm{XB}_{1}$ & 22.00 & 21.50 & 95.75 & 23.25 & 69.50 & 101.50 & 23.25 & 115.25 & 101.50 \\
\hline $\mathrm{A}_{2} \mathrm{XB}_{2}$ & 22.25 & 22.00 & 96.25 & 23.50 & 67.25 & 99.75 & 23.50 & 119.25 & 99.75 \\
\hline $\mathrm{A}_{2} \mathrm{XB}_{3}$ & 16.00 & 26.75 & 77.75 & 19.00 & 72.50 & 84.25 & 19.00 & 121.25 & 84.25 \\
\hline $\mathrm{A}_{2} \mathrm{XB}_{4}$ & 17.75 & 26.50 & 71.75 & 19.50 & 72.50 & 79.75 & 19.50 & 123.00 & 79.75 \\
\hline C.D. at $5 \%(B-A)$ & 5.30 & 1.83 & 8.851 & 4.63 & NS & 9.97 & 4.631 & NS & 9.97 \\
\hline $\mathrm{SE}(\mathrm{d}) \pm$ & 2.27 & 0.74 & 3.928 & 1.83 & 1.87 & 4.37 & 1.827 & 2.02 & 4.37 \\
\hline C.D. at $5 \%(\mathrm{~A}-\mathrm{B})$ & 5.07 & 1.89 & 8.15 & 4.99 & NS & 9.27 & 4.99 & NS & 9.27 \\
\hline $\mathrm{SE}(\mathrm{d}) \pm$ & 2.18 & 0.76 & 3.62 & 1.97 & 2.49 & 4.08 & 1.97 & 1.78 & 4.08 \\
\hline $\mathrm{CV} \%$ & 9.87 & 10.52 & 10.69 & 11.45 & 11.56 & 11.58 & 11.78 & 11.47 & 11.30 \\
\hline
\end{tabular}

$\mathrm{A}_{1}=$ Rice, $\mathrm{A}_{2}=$ Ragi, $\mathrm{B}_{1}=$ Mango + mahogany + aonla, $\mathrm{B}_{2}=$ Mango + mahogany + peach, $\mathrm{B}_{3}=$ Mango + mahogany + no filler, $\mathrm{B}_{4}=$ Fallow, NS= non significant

\section{References}

1. Cooper PJM, Leakey RRB, Rao MR, Reynolds L. Agroforestry and the mitigation of land degradation in the humid and sub-humid tropics of Africa. Experimental Agriculture.1996; 32:27-31.

2. Das B, Dhakar MK, Sarkar PK, Kumar S, Nath V, Dey P, Singh AK, Bhatt BP. Performance of mango (Mangifera indica) based agri-horticultural systems under rainfed plateau conditions of eastern India. Indian Journal of Agricultural Science. 2017; 87(4):521-7.

3. Dhillon WS, Chauhan SK, Jabeen N, Singh C, Singh N. Growth performance of inter-cropping system components and nutrient status of soil under hortisilvicultural system. International Journal of Environmental Resourcse Research. 2012; 1(1):31-38.

4. Kaushik N, Kumar V. Khejri (Prosopis cineraria) based agro-forestry system for arid Haryana. India. Journal of Arid Environment. 2003; 55:433-440.

5. Nath V, Das B, Yadav MS, Kumar S, Sikka AK. GuavaA Suitable Crop for Second Floor in Multi-Storied Cropping System in Upland Plateau of Eastern India. In I International Guava Symposium, 2006; 735:277-295.

6. Pareek OP. Arid zone fruits research in India. Indian journal of agricultural science. 1998; 68(8):508-514.

7. Singh B, Bishnoi M, Baloch MR. Tree growth and wheat yield in agri-horti-silvi system in the arid region of Rajasthan. Indian Forester. 2012; 138(8):726-732.

8. Singh G, Rathod TR. Growth, Production and resource use in Colophospermum mopane based agro-forestry system in north-western India. Archives of Agronomy and Soil Science. 2006; 53(1):13-23.

9. Swain SC. Performance and profitability study of different mango based intercropping systems in Eastern ghat high land zone of Odisha. Journal of Crop and Weed. 2014; 10(2):170-178.
10. Tripathi MK, Saini BC, Chaturvedi S. Growth and yield of intercropped wheat under Salix- Dalbergia agroforestry system. Annuals of Bio. of Agric. and Tech. Pantnagar, Uttarakhand, India, 2006. 